\title{
SHAKESPEARE'S ORIGINAL WILL: A RE-READING, AND A REFLECTION ON INTERDISCIPLINARY RESEARCH WITHIN ARCHIVES
}

\author{
By Amanda Bevan and David Foster
}

Much academic ink has been spilled on the importance of William Shakespeare's last will and testament, particularly as a source illuminating his life and character. Drawing upon recent archival research and technical analysis, this article details the processes by which interdisciplinary approaches to the will have resulted in a fundamental reinterpretation of what the contents of the will can tell us about Shakespeare's final years.

Keywords: William Shakespeare's will, law, archives, family settlements, conveyancing, methodology, interdisciplinary research, biography, literary history, conservation, multi-spectral imaging

\section{Shakespeare's family: dramatis personae}

William Shakespeare, gentleman of Stratford upon Avon

Anne Shakespeare his wife

- Susanna, their elder daughter

- Dr John Hall her husband (married 5 June 1607)

- Elizabeth Hall their daughter

- Hamnet, their son (died aged 11 in 1596)

- Judith, their younger daughter, and twin of Hamnet $\circ$ Thomas Quiney her husband (married 10 February 1616)

Joan Hart, his sister, and wife of William Hart, a hatter Francis Collins, his lawyer

\section{The will}

William Shakespeare's will was written 400 years ago, in brownish iron gall ink on one side only of three large paper folios, each signed by him. It looks like a draft with many alterations and corrections, some in a darker ink, with even the date being amended from 25 January 1616 to 25 March. $^{1}$ Some eight weeks after his death on 23 April 1616, this 'original' will was taken to the Prerogative Court of Canterbury, housed in Doctors' Commons near St Paul's Cathedral in London, by John Hall (the husband of his elder daughter Susanna and, with her, joint executor), and was proved

$\star$ DR AMANDA BEVAN is a principal records specialist at The National Archives. DAVID FOSTER is a teaching fellow at King's College, University of London. Versions of this paper have been presented at the Shakespeare Birthplace Trust (with Dr Katy Mair), at Senate House Library, University of London, and at King's College, University of London, and by Amanda Bevan, Katy Mair, Nicola Fleming and David Foster at the World Shakespeare Congress workshop on the will at The National Archives. Dates are given as if the year began on 1 January, except where otherwise stated. The authors wish to thank Paul Girvan, Imperial College, and Judith Skillen, King's College, University of London for their help and advice.

1 TNA, PROB 1/4. In this paper, 'folio' will be used to denote the physical paper, and 'page' to denote the text on the front of each folio. 
there on 22 June 1616. A parchment probate copy would have been made by the court for John Hall to take back to Stratford upon Avon to use as the authority to execute the terms of the will. He would have had to provide the court with an inventory of Shakespeare's goods, and a detailed account of the income to and expenditure from Shakespeare's estate that he had authorised as executor. Unfortunately inventories and accounts from this period were lost when Doctors' Commons, in the path of the Great Fire of London of 1666, was 'by the mercylesse rage of that devouring Element layd wast'. ${ }^{2}$ Fortunately the great parchment registers of the court, in which another copy of Shakespeare's will was made for safe-keeping, were not affected. ${ }^{3}$ Nor were the original wills, left behind by the executors and also kept by the court. Shakespeare's original will was rediscovered in the 1770s by Edmund Malone, and by the nineteenth century had become an iconic national treasure. A transcript is supplied as an appendix.

The will has had a profound effect on the construction of the Shakespeare biography. Views about his death have been affected more than anything else by the belief that wills were only written as death approached. This was indeed true in most cases: according to Helmholz, 'a very high percentage of wills were made at the very end of the testator's life ... Among the great, what we would call "estate planning" probably occurred. But . . most testators were near to death . . . and they knew it'.

The very existence of a will written within four months of death has obscured the possibility that at the age of 52, Shakespeare could well have hoped to match his parents' full 70 years of life, even though he and his sister Joan were the only siblings left of the original eight. As to the contents of the will, the general opinion (emerging over the nearly 250 years since the original will was first read as a source) is that Shakespeare behaved unkindly and ungenerously to his family, but that his family was unworthy of him. Most interpretations of the will (to be found in many of the biographies of Shakespeare) make a variety of assumptions, which can be briefly stated:

- Shakespeare was dying in January 1616, after his presumed poor health had caused him to retire unwillingly from London to Stratford.

- His will was unemotional, cold, unforgiving, sour.

- His daughter Judith Quiney, who was hateful to him (possibly because of the death of her twin brother in 1596), was treated poorly in the will.

- He mistrusted her and her new husband Thomas Quiney, a younger man and ne'er-do-well.

- His physical and mental state was made worse in late March 1616 when Thomas was accused of fathering an illegitimate son, who had just died with his mother, at or after the birth. ${ }^{5}$

- He roused himself from his sickbed to write Thomas out of the will in March, with the words 'my sonne in 1[aw]' being crossed out, and safeguards introduced against Thomas being able to touch Judith's money.

- His wife Anne was also hateful to him, or mentally deficient, as she was not mentioned in warm terms nor made an executor.

\footnotetext{
2 Recorded in the Privy Council Register on 2 Sept. 1666, TNA, PC 2/59 f. 89r; we owe this reference to Ruth Selman of The National Archives.

3 The registered copy is TNA, PROB $11 / 127 / 771$

${ }^{4}$ R.H. Helmholz, The Canon Law and Ecclesiastical Jurisdiction from 597 to the 1640s (Oxford, 2004), 397-8.

5 This fuller interpretation emerged from an investigation of Stratford church court records (now Kent History and Library Centre: Sackville Manuscripts U269/Q22 p. 66) by Hugh A. Hanley, 'Shakespeare's Family in Stratford Records' in Times Literary Supplement, 21 May 1964, 441.
} 
- He actively sought to prevent Anne claiming dower in his purchase of the Blackfriars Gatehouse in London.

- He made no provision for Anne except for the slighting bequest of a bed.

This list summarises the work of many authors over 250 years of Shakespeare biography and no attempt has been made here to exhaustively document the source of each of these arguments. Suffice to say that each idea in this list has gained sufficient currency to have circulated widely throughout the secondary literature.

\section{Process of interdisciplinary archival research}

For the four hundredth anniversary of his death, The National Archives (TNA) chose to re-examine the will, before it was shown in exhibitions with King's College, University of London (KCL), and at the Shakespeare Birthplace Trust in Stratfordupon-Avon. The will was examined physically as paper and ink, contextually to understand what it said, and textually to work out the writing history.

In fact, the work was undertaken in reverse order, and only grew into this structure over time. Dr Amanda Bevan, head of the legal records team, worked on and off from 2014 on the dating of the will, and with her Ph.D. student David Foster, on the legal context of the will and its bequests. Conservation work on the will and analysis of various scientific tests took place over the winter of 2015-16, undertaken by Nicola Fleming, conservation manager, and Dr Katy Mair, head of the early modern records team. These two had much wider roles too, over the whole array of Shakespeare documents at TNA, Katy as the curator (with the help of Dr Hannah Crummé) and Nicola as the conservator of the joint exhibition By Me William Shakespeare, with KCL, and with the long-term online exhibition Shakespeare Documented, curated by the Folger Shakespeare Library. ${ }^{6}$

In retrospect this looks like a relatively formal programme, but The National Archives engages with a wide variety of formal and informal approaches to archival research, as this article will illustrate. Real engagement with the contents of the will developed from a combination of working with an artist, with potential entrants to the archive profession, and with a collaborative Ph.D. student, alongside the more traditional dependence on professional skills expected within an archive.

Faced with an incredibly well-studied yet quite dry legal document, with iconic status, we were doubtful that anything new could be said. However, when in late 2013 the Friends of The National Archives commissioned the artist Anna Brass to make short films about the work of archivists, and at the same time the legal records team had to host a group of history undergraduates alongside the formal placement of two trainees from the Borthwick Institute on the Heritage Lottery Fund Transforming Archives scheme, the opportunity to combine film and enthusiasm (and the workstreams) was irresistible. The Borthwick trainees (Kerstin Doble and Francesca Taylor) needed to develop their palaeography, we wanted the undergraduates to experience the excitement of working with original records, and the artist was happy to make two films about Shakespeare's will. ${ }^{7}$

One film looked at the ways documents can be transmitted from the past to the

\footnotetext{
6 The online exhibition is at http://www.shakespearedocumented.org/ (accessed 31 Aug. 2016) and includes the most recent photographs of the newly-conserved will.

7 The films are freely available: This Holy Shrine at https://vimeo.com/112803186 and Backwards Divination at https://vimeo.com/91540285 (both accessed 31 Aug. 2016). They now bear an unexpected interest, as recording how the will looked before treatment.
} 


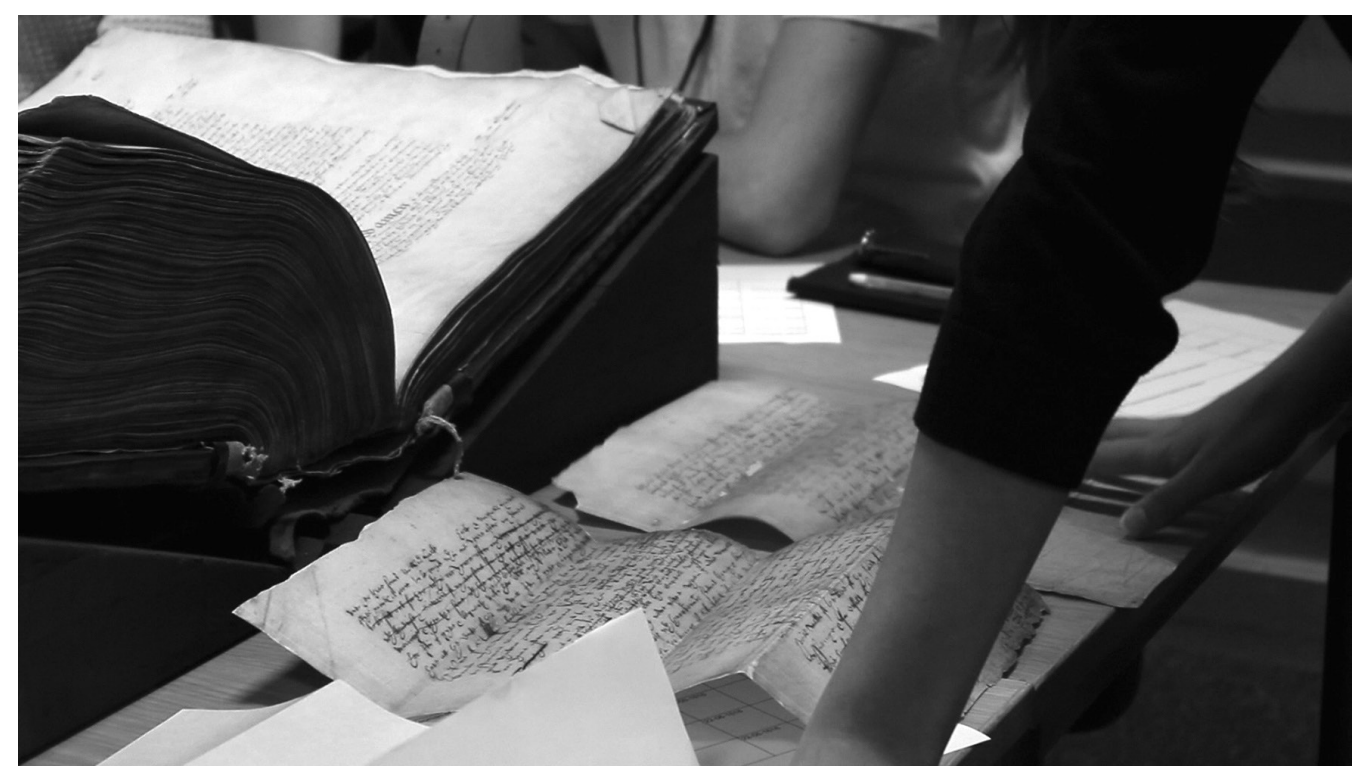

Figure 1: Facsimile of PROB 1/4 being compared to the registered will in PROB 11/127/771. Courtesy of The National Archives

present - as actual documents, as microfilms, as digital images, and in this case as a cultural icon mediated through these different interfaces. The other film set Shakespeare's will alongside the wills of the four other men proved in court on the same day, 22 June $1616 .{ }^{8}$ Although four of these wills were completely accessible as physical documents, the fifth - Shakespeare's - clearly was not. As Shakespeare's will is one of the treasures of The National Archives, it cannot actually be handled, let alone refolded or treated over-familiarly. Our film-maker dealt with this by making a prop - recreating the original will in facsimile (see Fig. 1), printing it off full size in colour from the TNA website, where it is freely available, ${ }^{9}$ trimming the flat A3 edges to the rather ragged edges of the original paper, and folding it along its old fold lines. The students found the bundles of wills proved in June 1616 (see Fig. 2), and put the facsimile back in with the rest of the folded wills, just the will of one man among many, 'William Shakspere', gentleman of Stratford upon Avon, Warwickshire. ${ }^{10}$ We read all five wills carefully, but were disappointed to find that comparing them did not really help us to understand Shakespeare's will any better: each man's personal circumstances and availability of heirs were just too different.

So the students and trainees departed, the films were completed, and we were left with a physical object to carry around, fold, unfold, read in TNA's cafe, or at home or on the bus. This element of demystification proved crucial in the eventual development of a new theory: in a sense it gave us confidence that new ideas could be raised, and other

\footnotetext{
8 The other four were of Martin Gravenor gentleman of Wrawby, Lincolnshire; Gawin Thacker yeoman of London; Thomas Bradford gentleman of Huntington, Herefordshire; and Thomas Hayward of Salisbury, Wiltshire.

${ }_{9}$ See http://discovery.nationalarchives.gov.uk/details/r/C198022 (accessed 31 Aug. 2016)

${ }^{10}$ TNA, PROB 10/332; we did not leave the facsimile there.
} 


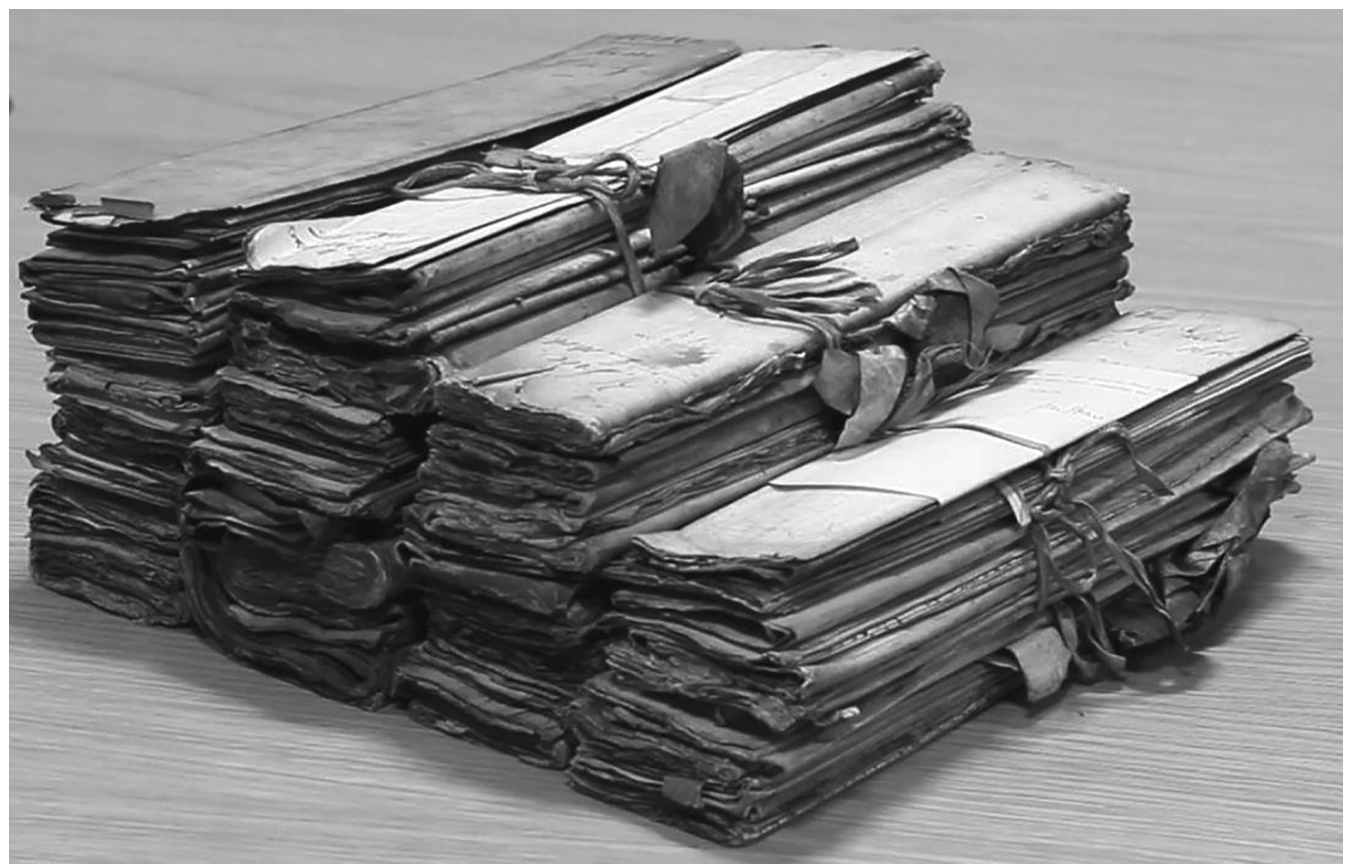

Figure 2: The bundles of original wills proved in June 1616 (TNA: PROB 10/332). Courtesy of The National Archives

contexts sought. There was a surprising difference between having even a standard A3 copy, and the physicality of the trimmed and folded facsimile will. Previous studies have generally been based on mediated copies - maybe sepia or monochrome images, or photographs, often reduced in size, but after an initial look, most researchers have quite understandably relied on transcripts. ${ }^{11}$ Although at least two scholars had seen the original in recent decades, they could not get deeply acquainted with it. ${ }^{12}$ And the digital image of course provided the ability to zoom in on each word, for really close examination.

However, being able to read the original does not make it quick to read, or allow instant comparisons. We therefore created a new transcript, line by line, and with an attempt to represent the visible variations in inks, crossings out and interlineations. ${ }^{13}$ The ability to use different fonts and different colours, and access to a colour A3 printer, were invaluable here, although they have been omitted in the appendix. More than anything, the tone of the new research was set not by the desire to reconcile existing theories and narratives, but instead to undertake a close reading of the will as a document reflecting Shakespeare's own intentions.

\footnotetext{
${ }^{11}$ The standard reproductions are in E.K. Chambers, William Shakespeare (Oxford, 1930) ii, plates XIX-XXI; in Samuel Schoenbaum, Shakespeare A Documentary Life (Oxford, 1975), 243-5; and in David Thomas, Shakespeare in the Public Records (1985), 28-30.

12 Jane Cox, 'Shakespeare's Will and Signatures', in David Thomas, Shakespeare in the Public Records and Joyce Rogers, The Second Best Bed: Shakespeare's Will in A New Light (Westport, Ct, 1993).

${ }_{13}$ Dr Hannah Crummé, TNA's Shakespeare researcher for the exhibitions, very kindly checked and corrected the transcript.
} 


\section{Methodology of interdisciplinary archival research}

In this article, we present a picture of collaborative research in The National Archives. By detailing the process by which this research was conducted, we illustrate some of the broader methodological issues attendant upon interdisciplinary research of this nature. In the course of this project, we found, for example, that whilst interdisciplinary research can tell us much that is new, we must be careful to frame our arguments in a form which is accessible to the widest possible audience. Dual and shifting authorial voices, writing from multiple disciplines, in a single article are liable to have access to greater range of audiences (with consequently greater research impact). By the same token, some of the detail from individual disciplines may become, in the eyes of initiates in that discipline, somewhat diluted, whilst, to others the niceties of arguments from unfamiliar disciplines may be lost. With this possibility in mind, we have striven to restrain our conclusions and conjectures only to those that can be directly supported from the extant evidence and to refrain from generality (and, indeed, excessive technicality) in our remarks. It must be recognised, therefore, that we write for a broad church and the style of writing employed here reflects this fact; throughout we have sought to ensure accessibility, sometimes at the expense of the technical detail often characteristic of monodisciplinary research and, at other times, not going as far in our conjectures as others might perhaps have liked.

\section{The dating history}

The dating history of the will has always been problematic, but the general view is that a first draft of January 1616 was substantially rewritten in March 1616, with Francis Collins turning his client's wishes into legal language on both occasions.

Part of the difficulty in following the various arguments published by multiple authors is the varied use of technical, legal terminology. In strict terms, the word 'publication' meant the point at which the testator approved or signed the will. ${ }^{14}$ In this period too, the 'witnessing' of a will did not need to occur at the moment the will was approved or signed..$^{15}$ The 'execution' of a will described the executor's responsibility to distribute the estate after the grant of probate (and not, as some legal dictionaries have defined it, the moment the testator signed the will in the presence of witnesses). ${ }^{16}$ E.K. Chambers reviewed the previous analyses in 1930, before concluding,

the following hypothesis seems best to fit the facts. In or before a January, probably of 1616, Shakespeare gave instructions for a will. Collins prepared a complete draft for execution in that month. It was not then executed, but on 25 Mar. 1616 Shakespeare sent for Collins. The changes he desired in the opening provisions were so substantial that it was thought best to prepare a new sheet 1 . . he made, and afterwards corrected, the slip of transcribing 'Januarij' from the old draft. ${ }^{17}$

\footnotetext{
${ }^{14}$ In this period, there was no statutory requirement that the will be signed by the testator; see M.C. Mirow, 'Last Wills and Testaments in England 1500-1800' in Recueils de la Societé Jean Bodin pour l'Histoire Comparative des Institutions, 1x, 1993, 72.

${ }^{15}$ See M.C. Mirow, 'Coke's Advice on Executing Wills of Land' in Relations between the Ius Commune and English Law, ed. R H Helmholz and V Piergiovanni, (Genoa, 2009), 244, and M.C. Mirow, 'Last Wills and Testaments in England 1500-1800', 72-3.

${ }_{16}$ The statutory requirement that a testator sign the will in the presence of witnesses was introduced by the Statute of Frauds 1677, 29 Car. II c. 3, and was, therefore, not applicable in this period.

17 Chambers, William Shakespeare, ii. 175.
} 
Jane Cox, in an influential opinion in 1985, stated that,

the shock of the [Quiney] scandal may have hastened Shakespeare's end, but it is more likely that he was already ill as the first draft of the will appears to have been made in January; in the seventeenth century men rarely disposed of their property until they were 'pinched by the messenger of death' ... The alteration of the date from January to March (at the top of the first page) suggests not only that an earlier draft was made at the beginning of the year, but also that the first page was rewritten ... The will was almost certainly redrawn so that Shakespeare could alter the provisions for Judith, who married in February 1616; her legacy is dealt with on the first (rewritten) page. The final alterations may have been following the Quiney scandal or the death of Shakespeare's brother-in-law, William Hart, on 17 April. ${ }^{18}$

For Park Honan, in 1998, Shakespeare,

was not at his last gasp, or 'a dying man', by 25 March 1616. On that day he was capable. Amidst the troubles of the sick room, he was perfectly aware that his legal will drawn up in January had not been signed or executed. To execute the will, he how called in again Francis Collins to whom he dictated so many changes that the attorney had to rewrite the will's first page. ${ }^{19}$

Stanley Wells, in 2002, considered that,

in January 1616 Shakespeare called his lawyer to draft a will. He had stopped writing plays and may have known that he had not long to live. Within a couple of months he had cause to change his bequests ... The later version of Shakespeare's will was prepared on 25 March . . The signatures on the will are shaky. Shakespeare was probably already ill [in March]. The best guess - it is no more - is that he was suffering from typhoid fever. ${ }^{20}$

Having a good colour facsimile allowed us to look carefully at the layout of the will on the pages, at the various crossings-through, and interlineations, and the relative darkness of ink in different places. It helped that the new transcript made it clear which interlineations and corrections appeared in a darker ink and which in the paler ink or inks used in the will.

It was clear at a glance that page 1 was, as so often stated, a longer replacement of a shorter text: the lines of text grew more cramped and closer together towards the end of the page. However, the changes at the top of page 2 seemed most significant. Here had been added two lines, to complete the bequests to the Hart family from the bottom of page 1. Below these two new lines were the original top three lines, crossed through, which had continued (from a previous page 1) the arrangements for Judith should she marry at some point in the future. The transcript of these top lines of page 2 makes these changes more obvious:

[new 1] unto her three sonnes William Hart [blank] Hart and Michaell Harte

[new 2] ffyve pounds A peece to be payed within one yeare after my deceas

[old 1] to be sett out for her within one yeare after my deceds by niny executors

\footnotetext{
${ }^{18}$ Cox, 'Shakespeare's Will and Signatures', 24-5.

19 Park Honan, Shakespeare: A Life (Oxford, 1998), 394.

${ }^{20}$ Stanley Wells, Shakespeare: For All Time (2002), 43.
} 


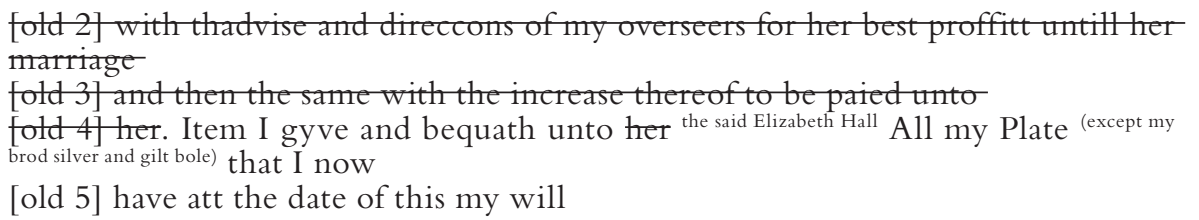

We read lines [old 1]-[old 4] as the completion of a bequest to Judith, started on the bottom of a previous page 1 . Money was to be set out (invested) for her within one year after Shakespeare's death by his executors, for her best profit until her marriage and then the same with the increase thereof to be paid unto her. Given that page 1 was written in January 1616 in expectation of Judith's marriage in February 1616 and whether or not page 1 was altered in March 1616 - this previous bequest does not make sense within this timeframe. For it to take effect, Shakespeare would have had to have died on or after January 25 but before Judith's wedding on February 11, the will proved immediately and the money not merely invested but a profit created, all in the intervening 17 days.

This is a nonsense: nobody would write such a will in such circumstances. We concluded that these lines must therefore relate to an earlier bequest in an unsuspected older will, planning for a possible future marriage to take place a significant period after Shakespeare had died with Judith still unmarried. The existence and crossing through of these lines could only mean that page 2 was a physical remnant of this earlier will. The bequest of the Blackfriars Gatehouse on this page gave us an earliest date for this will of 1613, as the Gatehouse was bought in March 1613.

But if page 2 came from an older will, did page 3 as well? We found a clue in the bequest of all of Shakespeare's plate to Judith on the next lines [old 4] and [old 5]. This was altered by an interlineation, apparently in the same ink as the new top lines, substituting his grand-daughter Elizabeth Hall as the receiver of the plate 'except my brod silver and gilt bole'. This same bowl appears on page 3 written within the text, as a direct bequest to Judith. If Page 2 and Page 3 had been written at the same time, it is odd that such a change of mind had occurred in the time taken to write the two pages.
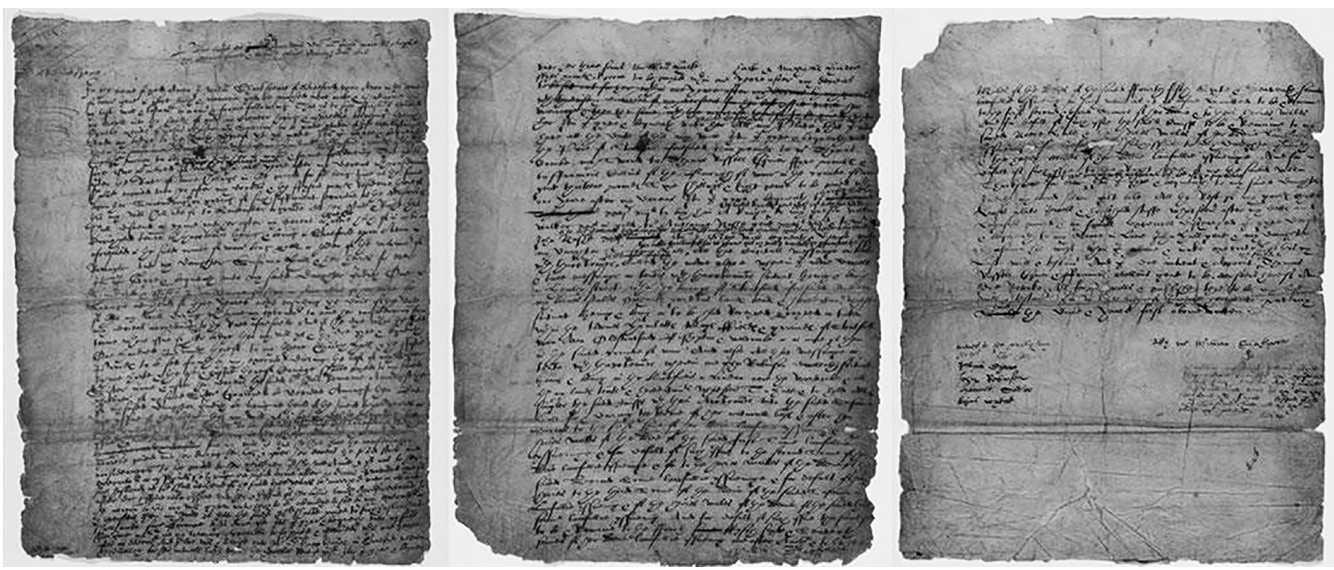

Figure 3: Shakespeare's will as seen by the human eye (470nm spectrum) - all text is visible on all three pages. The dark-ink interlineations are quite clear.

(Crown Copyright The National Archives, Image created by the British Library Board) 
After some hesitation, we concluded that of the three pages, one was indeed written at a different time - but that it was not page 1 as previously thought. Instead we identified page 2 as the remaining page of a previous (and unknown) three-page will from probably 1613, given a new page 1 in January 1616 in preparation for Judith's marriage, and new page 3 at the same time for re-witnessing. There were changes made in March 1616, the dark-ink alteration of the date to March and the dark-ink interlineations, but these had nothing to do with the Quiney affair. They comprised two formal changes (to clarify his daughters' expectations to each other) and a sequence of personal bequests. These included money for mourning rings for his Stratford friends and his theatre 'fellowes' Richard Burbage (who followed him to the grave three years later) and John Heminges and Henry Condell (the compilers of his collected plays in the first folio, published in 1623). The final one was the famous second-best bed to his wife. But the last use of the dark ink appears to have been for the signatures of the four last witnesses, Julius Shawe, John Robinson, Hamnet Sadler and Robert Whattcott.

\section{Technical evidence for the re-dating}

So now we had a potential re-dating, emerging just as plans were firming up for the will to be exhibited for the Shakespeare 400 celebrations. However, this new interpretation was based solely on reading and thinking about a text known since the 1770s. Going any further to provide a physical proof would require a significant expenditure of effort by TNA's collection care department before detailed technical examination could take place.

Because of the many previous repairs to the will, the last in the 1990s, it was not possible to carry out detailed technical analysis of the paper and ink until the added layers of silk and lining paper had been removed. Nicola Fleming undertook much work to find the safest procedure. She made samples using non-accessioned manuscripts with similar paper and iron gall ink, which were first repaired, using materials and techniques from the 1990s' conservation treatment, and then artificially aged. Three different removal methods were then considered: aqueous treatment (highest risk), mechanical removal, and low-moisture enzyme treatment (lowest risk). The enzyme treatment was decided on, and tried out on the constructed samples. In late 2015, four conservators (Nicola Fleming, John Abbott, ${ }^{21}$ Holly Smith and Joanna ThompsonBaum) worked over three months to painstakingly remove as much of the layers as they could, before reversible repairs were undertaken.

The will now had all infills and repairs removed from the back of each folio, with all silk and lining paper removed from folio 3, and part removal of the lining paper from the backs of folios 1 and 2. This allowed for the further non-invasive technical examination of each folio. Nicola was able to identify from the chain and laid lines, and the now visible watermarks, that folios 1 and 2 came from different paper stocks: unfortunately folio 3 was too damaged, from acting as the outer wrapper and from previous repairs, to be helpful. The margins on the left side of the text (created by folding the paper lightly before starting to write) were the same on folios 1 and 3 , and wider on folio 2 , supporting the view that page 2 was written at a different time.

Further examination was also done under near infra-red light, by University College, London, which picked out the annotations made by the Prerogative Court of Canterbury in a different, carbon, ink, but did not show much variation in the iron

${ }^{21}$ John Abbott has the unique distinction of having conserved both Domesday Book and Shakespeare's will in his 43 year career at The National Archives. 
gall ink of the rest of the text. More tests were undertaken at the British Library, using multi-spectral imaging, where the will was exposed to ultra-violet, visible and infrared rays and the reflected radiation recorded in a camera sensitive to these regions of the spectrum. This showed up a clear difference in the inks over the infra-red spectrum, with the main text on pages 1 and 3 disappearing from view at the same time, while the ink on page 2 remained visible for longer. The continuing visibility of the page 2 ink suggests that the text on page 2 was written using a different ink than that used for pages 1 and 3. The dark-ink change of date to March and interlineations remained visible longest, across all three pages.

So we had an overview result that indicated pages 1 and 3 may have been written with one ink (Ink 1), and page 2 to have been written using a different ink (Ink 2), thus supporting - if not the exact re-dating of page 2 to the year 1613 - at least an understanding that it pre-dated pages 1 and 3. After this, Katy Mair and Nicola Fleming began the more difficult job of working out the interlineations and corrections. The dark-ink (Ink 3) interlineations appear to be the same ink, from March 1616, as they include the change of date: however, there is some variation of visibility, which may or may not be significant. For example, the first two witness signatures disappear before the last two. ${ }^{22}$ There also appears to be another ink (Ink 4) used by Francis Collins and Shakespeare when they witnessed the last page.
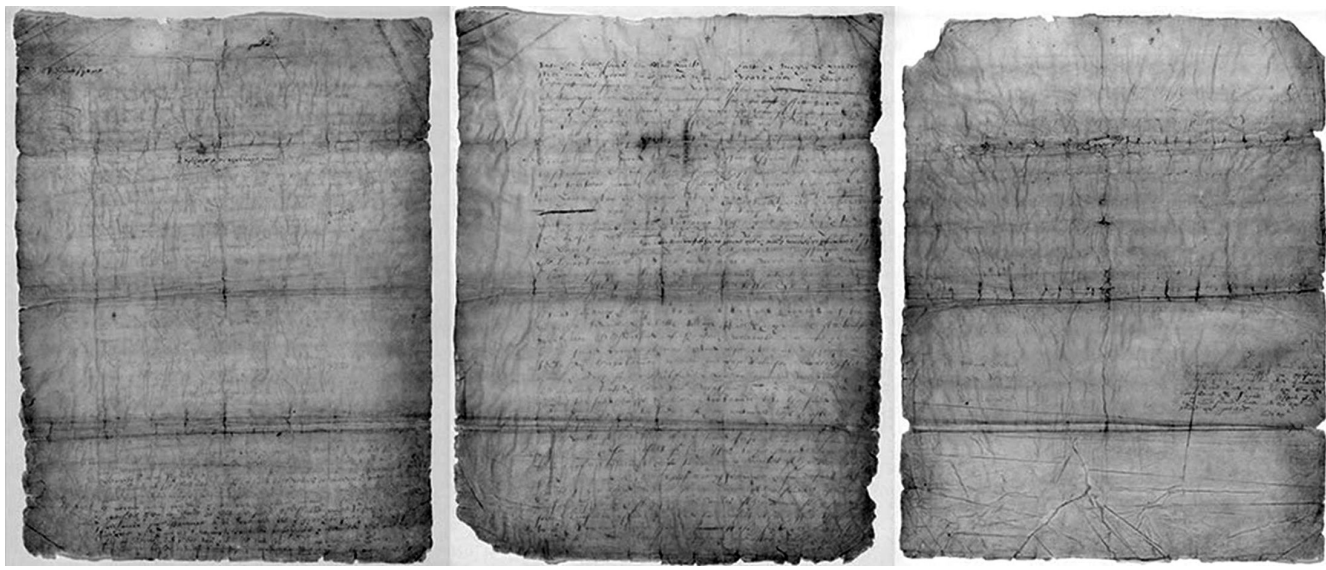

Figure 4: Shakespeare's will under infrared rays (1050nm spectrum) - most text has faded away from pages 1 and 3. Page 2 has more text remaining. The dark-ink interlineations can be seen on all pages. (Crown Copyright The National Archives, Image created by the British Library Board)

\section{Implications of the new dating}

Now we know that Shakespeare was the kind of man who kept his affairs in good order and his will up-to-date as his family and business circumstances changed. But how does this affect our understanding of the will? It is clearly a business-like legal document, unemotional by format and not thereby indicating a lack of affection, but reflecting long-term planning for his family by Shakespeare with the help of his lawyer and friend Francis Collins. The existence of a page of an earlier will indicates

\footnotetext{
${ }^{22}$ Nicola Fleming and Katy Mair will be publishing a more detailed report on the various examinations and analyses.
} 
that he adapted the settlement of his estate as circumstances changed. This suggests an understanding of the vagaries of life, and an engagement with the reality of property holding. In February 1613, Shakespeare lost his last brother Richard, and in March he invested in the Blackfriars Gatehouse property in London. Page 2 of the surviving will mentions this property: this earlier will may well have been written (or perhaps even rewritten) because of these two events.

The fact that this will is dated 25 January 1616 does not therefore imply that William Shakespeare was seriously ill or in expectation of death in early 1616, or that he was seriously ill in 1613. Although more people in the seventeenth century made deathbed wills than was later the case (because the rules governing will-making were simpler), by no means all did, and many testators did make wills in advance. We cannot assume that a man who died in April after writing a will in January did so because he was fatally or chronically ill: reading back to years of chronic depression, alcoholism or syphilis is taking speculation too far. This biographical standard will need re-examination. Perhaps Shakespeare's death was not long foretold, by him or anyone else.

The story, current in Stratford in the 1650s, referred to by Stanley Wells may bear some truth: that Shakespeare, after a merry meeting with Ben Jonson and Michael Drayton in Stratford, caught a fever and died. ${ }^{23}$ Given that his brother-in-law William Hart died six days before Shakespeare, it may mean that a fever was prevalent in Stratford in March and April 1616, even if it actually killed few people. ${ }^{24}$

Certainly the whole family must have been in a sad way. An eight week gap between death and the executor seeking probate of the will seems unusually long: perhaps John Hall, the executor, was kept busy in his medical practice in these weeks.

Verghese's description of a 'typhoid state' makes it clear that Shakespeare knew what a fever could lead to:

The "typhoid state" occurs classically with typhoid and typhus fevers but is also seen in other infectious diseases. Clinical descriptions of this state as "muttering delirium" or "coma vigil" refer to the peculiar preoccupied nature of the stupor. Picking at the bedclothes and at imaginary objects (carphology and floccillation) are characteristic, as is muscular twitching (subsultus tendinum). There is strong evidence that the death of Falstaff in Shakespeare's Henry $V$ is a vivid description of the typhoid state. ${ }^{25}$

So here at last are some words of Shakespeare's own: Mistress Quickly on Falstaff's last days:

A' made a finer end and went away an it had been any christom child; a' parted even just between twelve and one, even at the turning o' the tide: for after I saw him fumble with the sheets and play with flowers and smile upon his fingers' ends, I knew there was but one way; for his nose was as sharp as a pen, and a' babbled of green fields. 'How now, sir John!' quoth I 'what, man! be o' good cheer.' So a' cried out 'God, God, God!' three or four times. Now I, to comfort him, bid him a' should not think of God; I hoped there was no need to trouble himself with any such thoughts yet. So a' bade me lay more clothes on his feet. ${ }^{26}$

${ }^{23}$ Wells, Shakespeare: For All Time, 45.

${ }_{24}$ The burial register for Stratford does not suggest an epidemic: Shakespeare Birthplace Trust, DR243/1, folio 46 recto, viewable online at http://www.shakespearedocumented.org/.

${ }_{25}$ A[braham] Verghese, "The "typhoid state" revisited' in American Journal of Medicine, 1xxix (3), 1985, 370-2.

${ }^{26}$ William Shakespeare, Henry V, Act 2, Scene 4. 
If Shakespeare were indeed enduring such sequences of confusion, lucidity and suffering, it is clear why the dark-ink interlineations were so brief-and also so personal in effect and intent.

\section{A new reading of the will}

Returning to the more formal legalistic words commissioned by Shakespeare, early in 2015 Amanda Bevan asked David Foster a question about the provision in the January 1616 will for Judith. David was at this point a collaborative Ph.D. student, TNA's first such student in law, working on early modern litigation in the court of chancery and building on the long-term work done by the legal records team to make these records more accessible. ${ }^{27}$ From this question flowed a new understanding of Shakespeare's will. This is a very good example of how hosting a collaborative Ph.D. student can really benefit an archive: the cross-disciplinary access, combined with the experience of working together, encouraged both to look further. Neither expected to work on Shakespeare's will, and both contributed to and checked each other's enthusiasm. Both also discovered the ease of misunderstanding between the lawyer's particularity and the more general interpretations of the law by followers of other disciplines: it was not just what we knew, but how we were trained to think.

From our extended discussions, we began to pick apart the terms of the will, and to think beyond its text. It was clear from reading about the will that confusion abounded over the provisions made by Shakespeare for his wife and children, and that a new statement of the common legal and cultural expectations of family life in a reasonably well-off family would be helpful.

We now think that William Shakespeare had made an earlier, inter vivos, settlement within his family, which was not restated in the will, as well as the later settlement in the will (which provides the best evidence for the earlier one). Anne was not mentioned as an heir, because she was not one: she was a wife with established protection for her widowhood, created outside the will. Wills were made to alter the usual rules of inheritance, which applied if no will was made. Wives had a different set of rules to govern continued marital support for their widowhood, which could be varied by settlements, typically taking the form of a prenuptial jointure.

\section{Usual practice on settlements}

On marriage, a woman's legal status was transformed from being a feme sole (a single woman or widow) to being a feme covert or covert-baron (a married woman):

By marriage, the husband and wife are one person in law ... that is, the very being or legal existence of the woman is suspended during marriage; or at least it is incorporated and consolidated into that of her husband; under whose wing, protection and cover, she performs every thing; and is therefore called in our lawFrench a feme covert ... [and] is said to be covert-baron, or under the protection and influence of her husband, her baron or lord ... Upon this principle of an union of person in husband and wife, depend almost all the legal rights, duties and disabilities that either of them acquire by the marriage. ${ }^{28}$

\footnotetext{
${ }^{27}$ He was then based at the Law Department of Queen Mary, University of London, supervised by Professor Michael Lobban, and at The National Archives co-supervised by Dr Amanda Bevan.

${ }_{28}$ Giles Jacob, Law Dictionary, ed. T.E. Tomlins (London 1809) under BARON AND FEME.
} 
So under this doctrine of coverture, a woman's legal personality was subsumed to that of her husband. All of the property she held prior to the marriage became vested in her husband. She could not make contracts, nor could she sue or be sued in her own name. The husband became responsible for the support and maintenance of his wife during their married life and her coverture: her property became his property; her earnings, his earnings. From the 1580s, it became increasingly common for the wife's family (if sufficiently wealthy) to set her up with a 'separate estate', where part of her property was protected by a trust from both her husband and her husband's creditors. ${ }^{29}$

When the husband died and his wife became again a feme sole, she was still expected to benefit from his care. A husband's responsibility for his wife's support was supposed to continue after his death. So in her widowhood, she would have had some form of life interest, in the form of dower or a jointure established in the lifetime of her husband. Traditionally, the widow had a claim under the common law to dower - a third of the land held by her husband during the marriage, for her life. Dower could be claimed on land of which the husband was seised (that is land held in fee simple - a form of free hold tenure, providing the greatest right in land which an individual can hold - and not for example in copyhold or leasehold tenure) during the coverture, and could even attach to land which the husband had sold. As the market in land quickened, however, the avoidance of dower became increasingly more attractive to landowners: selling or buying land burdened with a potential claim to dower was fraught with future problems.

From the late fourteenth century, the preferred method of planning to support a widow was jointure, in which the wife was given a life interest in specific lands (usually less than the third covered by dower) ${ }^{30}$ held by her husband, and recorded in a marriage settlement. ${ }^{31}$ This jointure was given in lieu of dower, and the Statute of Uses $1536^{32}$ specifically prevented widows claiming both their dower and their jointure. ${ }^{33}$ The husband was still able to devise these jointure lands by will, but the land would not actually pass to the named heir while the widow lived.

Settlements covered far more than the husband and wife, and were usually executed by a private deed, after negotiations between the two families. ${ }^{34}$ Although settlements were usually made on marriage, to cover future eventualities, they could also be made after marriage as a family settlement (useful if the family's wealth substantially increased from a low base, as in the Shakespeare family).

In a family settlement, the estate was reserved for an expected elder son, the male heir, and after him to the next male heir, and so on (this system was for passing on land within the male line). From the estate, the heir was expected to provide the income specified in the settlement for the widow's jointure for her maintenance, for any younger sons to set them up, and for any daughters for their portions - money

\footnotetext{
${ }^{29}$ For further details on the early history of the married woman's separate estate, see M.L. Cioni, Women and Law in Elizabethan England with particular reference to the court of chancery (1985) and N.G. Jones, 'Trusts in England after the Statute of Uses: A View from the $16^{\text {th }}$ Century' in Itinera Fiduciae: Trust and Treuhand in Historical Perspective, ed. R Helmholz and R Zimmermann (Berlin, 1998), 186-8.

${ }^{30}$ For a gendered study of provision for daughters and widows, see Eileen Spring, Law, Land and Family: aristocratic inheritance in England, 1300-1800 (Chapel Hill, 1993), chapters 1 and 2.

31 J.H. Baker, Introduction to English Legal History, (4 ${ }^{\text {th }}$ edn, 2000), 270.

3227 Hen VIII, c. 10.

33 Although a jointure would only bar dower if it were granted before marriage. Postnuptial jointures preserved in the widow the right to choose between her dower and her jointure. As a result, trusts to bar dower, even where jointure had been given, remained a necessity in the conveyancing context.

34 'The common type of marriage settlement protecting women's property usually appears in the historical record only in passing, in the context of some other, more immediately pressing, issue': Amy Louise Erickson, Women and Property in Early Modern England (1993) 113.
} 
for their own marriage settlements. These future liabilities were set up as charges on the estate, which the heir was legally obliged to pay (discharge).

\section{An earlier Shakespeare family settlement}

We do not have any direct evidence for how the Shakespeare family planned their finances to provide security for family members in the 1580 s and 1590 s. ${ }^{35}$

William Shakespeare, under-age and still reliant on his father, married Anne Hathaway in 1582 with little property of any kind between them. Richard Hathaway had bequeathed his daughter 10 marks $(£ 613 \mathrm{~s} 4 \mathrm{~d})$ to be paid to her on the day of her marriage. ${ }^{36}$ There were three children born early in the marriage: Susanna in 1583 and the twins Hamnet and Judith in 1585.

Eventually, he began to make his way in the world in London, accumulating savings to provide security for his family. It is possible that a post-nuptial settlement therefore took place towards the later end of the period 1585 and 1596, when Shakespeare still had a direct male heir in his son Hamnet, as well as two daughters, but as yet no significant landed property. ${ }^{37} \mathrm{He}$ could have made arrangements for his wife, and for the children, with his son Hamnet as the heir, and his daughters to have money for marriage portions. His daughters' portions seem likely to have been set at f,100 each, as this is the sum deliberately described as Judith's portion in the 1616 will: settlements often specified a fixed sum to be divided between any daughters.

Shakespeare's increasing wealth is made clear by at least four substantial investments in property (as opposed to his theatre shares) made between 1597 and 1613, and by his inheritance on his father's death in 1601 of the family's double house on Henley Street:

- 1597 - c. £120 for New Place, Stratford;

- 1602 - £320 for 107 acres in the fields within the parish of Old Stratford;

- 1602 - a messuage in Chapel Lane, Stratford held by copyhold tenure of the manor of Rowington;

- 1605 - $\mathcal{E}_{440}$ for the lease of a portion of the tithes of Old Stratford for 31 years;

- 1613 - £140 for Blackfriars Gatehouse, London (with a mortgage).

Each of these purchases altered the family circumstances: there may have been other arrangements made for the future that we simply do not know about because the deeds no longer survive.

Evidence of an earlier settlement made by William Shakespeare for his family exists within the 1616 will. It indicates that he had promised Judith a $f_{100}$ marriage portion in an inter vivos family settlement, but had deferred payment of that portion until his death. The evidence is a late dark-ink interlineation added on page 1, where the first bequest of $£, 100$ to Judith Shakespeare is clarified by the deliberate addition of the phrase 'in discharge of her marriage porcion'. The phrase implies that there was a recognised debt to discharge. A family settlement granting a marriage portion created an obligation on the father to pay the money promised. The obligation typically arose upon the daughter's turning 18, or on the date of her marriage. Judith was 31 on her marriage, and had clearly not received her portion either at 18 or on her marriage in

\footnotetext{
35 There may have been relevant records among the deeds and evidences taken from New Place in 1637: TNA, C 7/49/115.

36 TNA, PROB 11/64/352 (ff. 238v-239).

37 Hamnet died in August 1596.
} 
February 1616. It was not unusual for the money to be paid only after the death of the bride's father. Commenting on this practice, Habakkuk has stated:

It was to the advantage of the children that the portions became payable when they needed them. Daughters were likely to make poorer marriages if the payment of their portions were deferred until the death of the father ... [But] the father looked on the matter in a different light. Ideally he was interested in maximum flexibility. Though he might want the power to improve his daughter's prospects by raising the money for her portion on marriage, he was usually anxious to ensure that he was under no legal obligation to pay the portions until his death. ${ }^{38}$

Although Shakespeare chose to delay payment until his death, he remained under a legal obligation to Judith throughout his life until her portion was paid.

This interlineation is there as a safeguard, to make it clear that this $\mathcal{E}_{100}$ is left to Judith in satisfaction of her portion, and is not a further $\mathcal{E}_{100}$ gift. So a previous settlement of some kind can be assumed, which is here being recognised, while new bequests outside the settlement were also added.

This interlineated phrase may seem a small point from which to extrapolate, but this extrapolation does match usual practice among landowners at this time. The lack of any specific mention of an earlier settlement in the will is also usual; as Erickson points out, 'the frequency with which property settlements are implied without being specified suggests that such settlements were sufficiently common not to need careful documentation in subsequent probate records' ${ }^{39}$

By the time he died, Shakespeare had a severe shortage of male heirs: his nearest male relatives were his sister Joan Hart's three sons. But on the death of his own son Hamnet in August 1596, he still had three younger brothers - Gilbert, Richard and Edmund. All the brothers were raised to gentle status, by the grant of a coat of arms to their father John in October 1596. ${ }^{40}$ Although none of them married and all predeceased him, until the death of Richard in February 1613 Shakespeare still had a male heir to whom he could give precedence over his daughters Susanna and Judith, if he so chose. It is possible that he may have preferred to leave the estate to a brother, to carry on the Shakespeare family as Warwickshire gentry, while providing generously for his daughters.

\section{Susanna's marriage in 1607}

Susanna married Dr John Hall on 5 June 1607. She may have had a portion of $\mathcal{N}_{100,}$ like Judith. Whilst there is no documentary evidence that Susanna had a marriage settlement, the common practice of the time suggests that it is highly likely that her father would have made provision for his daughters (as indeed he did for Judith, discussed below).

Macdonald has discovered a memorandum made in the early 1620 s by Sir Simon Archer of Tanworth, concerning the 107 acres of lands in the fields of Old Stratford. This mentions that 'Mr Combe sold [. . . the land] to Will[ia]m Shackspeare who had one daughter and gave the said land to w[i]th his daughter in marryage to Mr Hall

\footnotetext{
38 See J.H. Habakkuk, Marriage Debt and the Estates System: English Landownership 1650-1850 (Oxford, 1994$), 122$.

39 Erickson, Women and Property, 145.

40 See Adrian Ailes, “A herald, Kate? O put me in thy books": Shakespeare, the Heralds' Visitations and a New

Visitation Address' in Heralds and Heraldry in Shakespeare's England, ed. Nigel Ramsey (Donington, 2014), 105-24.
} 
of Stratford who hath now all the lands . . . ${ }^{41}$ From this brief passage Macdonald has concluded that there was a marriage settlement between John Hall and Susanna Shakespeare in 1607, and that her father 'may have retained a life interest, making the bequest in the will no more than a reiteration of the status quo, the land having already been settled on them and their issue'. ${ }^{42}$

Unpacking the phraseology of the memorandum does not indicate when this 'gift' was given, nor what form it might have taken. We do know that Archer got one detail wrong (i.e. the reference to Shakespeare's one daughter); it is possible that, writing some years after the fact, he may have elided the Halls' later possession of this estate with the time of Susanna's marriage. We also now know that in 1613 the Halls were expecting to receive this estate after Shakespeare's death (from page 2 of the will), and were in fact possessed of it after he did die in April 1616. Quite simply, we have no evidence that the Halls held this land before Shakespeare's death, or that they were granted the remainder of the estate in a family settlement, otherwise than by the general words in the will devising the lands and tenements in Old Stratford (and elsewhere) to Susanna with various remainders to keep it within the wider Shakespeare family.

With all Shakespeare's brothers and his only son having predeceased him by 1613 , he was left with his two daughters Susanna and Judith as his heirs. The usual English inheritance pattern in such a case would have been an equal split between the two as joint heiresses or coparceners. ${ }^{43}$ This pattern could be altered by will, and the fact that he did so, in favour of Susanna, has generally been seen as proof that he thought little of Judith and her husband Thomas Quiney. However, this disposition in favour of Susanna may be explained less by any personal preference for her over Judith, and more by his intention to set up a dynasty by endowing an elder daughter with the real estate, subject to obligations to look after the younger daughter. This was an obvious solution to the lack of a son - and a solution that may have appeared all the more natural given the role of female primogeniture (for lack of a male heir) in local customary law. We know from a case in Chancery in 1595 that copyhold land held of the manor of Rowington in the Forest of Arden, was subject, for want of male heirs, to the local custom of female primogeniture. ${ }^{44}$ We also know that in 1602 Shakespeare had bought a messuage in Stratford which was part of the manor of Rowington, and that he took pains in his will to get Judith to relinquish any right she may have thought she had to this property, giving her $£, 50$ to do so. So perhaps the inclination to treat an eldest daughter as a substitute for a missing son may have been part of the local culture and expectation. ${ }^{45}$

\section{A new settlement by will, 1613}

It was after the death of Richard (his last brother) in February 1613, followed in March 1613 by the purchase of the Blackfriars Gatehouse property in London, that

\footnotetext{
${ }^{41}$ Shakespeare Birthplace Trust, DR37 Box 113/15, quoted in Mairi Macdonald, 'A New Discovery about Shakespeare's Estate in Old Stratford' in Shakespeare Quarterly, xlv no 1 (1994), 87.

42 Macdonald, 'A New Discovery', 89.

43 Giles Jacob, Law Dictionary, under COPARCENARS [sic]: 'such as have an equal portion in the inheritance of an ancestor; and by law are the issue female, which, in default of heirs male, come in equality to the lands of their ancestors'.

${ }_{44}$ As part of the background to the suit White $v$ Gratwood, the decree declared that 'land customary ... parcel of the said manor of Rowington ... . [is] descendable for faulte of heires males to theldeste heire female for tyme whereof memory of man is not to the contrary', TNA, C 78/84 no 19.

${ }^{45}$ For examples of the transmission of custom across generations, see Andy Wood, The memory of the people: custom and popular senses of the past in early modern England (Cambridge, 2013).
} 
Shakespeare had his will drafted or redrafted to take account of these new circumstances. Shakespeare purchased the Blackfriars Gatehouse property in trust for himself (that is, the property was held by trustees for his benefit) and he used his will to express what should happen to this property on his death. ${ }^{46}$

In this 1613 will (which we argue still exists in part, as page 2 of the will submitted for probate in 1616), it is clear that Shakespeare had established Susanna, his elder daughter, and her potential sons, as the heirs of the family property. This is written in Francis Collins' precise legal language:

during the terme of her naturall lief and after her deceas to the first sonne of her bodie lawfullie yssueing and to the heires Males of the bodie of the saied first sonne lawfullie yssueinge and for defalt of such issue to the second sonne of her bodie lawfullie ysueinge

specifying the line of succession down to Susanna's potential seventh son. ${ }^{47}$ Susanna at this point had a 5-year old daughter, Elizabeth, so further children were still a possibility. In the 1613 will (and again in 1616), Susanna was left

all that Capitall Messuage or tenemente with thappertenaces in Stratford aforesaid called the newe place wherein I now Dwell and two messuags or tenementes with thappurtenances scituat lyeing and being in Henley Streete within the borough of Stratford aforesaied And all my barnes, stables, Orchardes, gardens, landes, tenementes and hereditaments whatsoever scituat lyeing and being or to be had receyved, perceyved or taken within the townes and Hamletts, villages, ffieldes and groundes of Stratford upon Avon, Oldstratford, Bushopton and Welcombe

and was required to provide from these properties the cash for all other bequests, including the major ones to Judith.

In 1613, Judith was left (as far as we can infer without the first page) her portion of $\mathcal{L}_{100}$, a sum of money to be set out (invested) for her by the executors and the capital to be paid with the interest on her marriage, all her father's plate, and a contingent interest in everything left to Susanna and Elizabeth, if intervening heirs did not exist.

\section{Changes to the settlement made on Thursday, 25 January 1616}

In January 1616, Shakespeare therefore had an existing will that he wanted to update. He knew that Judith was shortly to marry Thomas Quiney, a young man known to the family for all his life. He chose to revisit the 1613 will, to provide for Judith more fully. Consulting with his lawyer, Francis Collins, they came up with a draft that utilised the second page of the 1613 will, but replaced the first and third pages.

This first page made new provisions for Judith, and the second page was corrected and added to, reflecting these new arrangements. Page 2 was altered to leave the plate to his grand-daughter Elizabeth Hall, with an interlineation made at the same time of '(except my brod silver and gilt bole)'. We also know that page 3 was rewritten in January 1616 because the bequest to Judith of the silver gilt bowl was written as part of the text.

\footnotetext{
${ }^{46}$ This is expressed in the indenture of $10 \mathrm{Feb}$. 1618, which transferred the property to a new set of trustees (from the London-based John Jackson, John Heminges and William Johnson to the Stratford-based John Green and Mathew Morrys: Folger Shakespeare Library, MS Z.c.22 (45).

${ }^{47}$ This text is quoted in the 1618 indenture, down through the seven potential sons, and Elizabeth, and eventually to Shakespeare's 'right heirs'.
} 
A further change may have been written into the new page 3 , following on from the listing of Susanna's potential male heirs on the old page 2. By 1616, Susanna had had no successful pregnancies since 1608. The redrafted page 3 allows Susanna's daughter Elizabeth to succeed to the estate if she had no brothers, and to pass it on to any sons (but not daughters). It does not give the same opportunity to any future daughter Susanna might bear. The implication is that by 1616, Shakespeare did not expect Susanna to have any more children. Instead, if Elizabeth herself died without sons, the remainder of the estate was limited to her aunt Judith Shakespeare, and to her potential sons; if none, to his own right heirs, that is, those entitled according to the common law rules of descent. ${ }^{48}$ (Leaving property to one's right heirs was a common clause found in wills. Such a clause ensured that, if all the testator's named legatees had passed away by the time of the testator's death, the property would pass to one of the testator's descendants.)

\section{Witnessing the will}

A further need to rewrite page 3 in January 1616 would have been to republish and witness the will. Significant changes had been made in page 1 and page 2, giving Judith an increased provision, and diverting the plate to Elizabeth. The dating clause on page 3 is only 'the Daie and Yeare first above written' with the date appearing on page 1. Page 3 is signed 'By me William Shakspear' in a firm and fluent hand, as part of the January settlement. Pages 1 and 2 however have just the remains of Shakespeare's signature at the bottom of each page, in what may be a shakier hand. It is not really possible to identify the ink used in these two signatures as the pages have crumbled here, and have been heavily restored which has affected the results of the multi-spectral imaging. Perhaps he signed these pages in March, to validate the smaller changes we think were made then.

Francis Collins signed page 3 at the same time (January) as Shakespeare, in what we have called Ink 4, as 'Witness to the publishing hereof' - meaning that Shakespeare had signed the will in Collins' presence. Clearly Collins knew what was in it, but other witnesses need only have signed the document knowing that what they were signing was the will. The other four witnesses signed using the dark ink (Ink 3) which we associate with March 1616. We also know that the last two (Hamnet Sadler and Robert Whatcott) signed together, as their signatures were still fresh when folio 2 was replaced on top of folio 3: removing the layers of backing from folio 2 revealed an imprint of the wet ink. It would appear, therefore, that Shakespeare had published his will, in the presence of Francis Collins, in January, after which time, certain clauses were interlineated before the will was witnessed by Shawe, Robinson, Sadler and Whatcott in March.

\section{Judith's marriage settlement, 1616}

Thomas Quiney's appearance before an ecclesiastical court on 26 March 1616 for fathering an illegitimate child has often been claimed to be the cause of significant distress to Shakespeare, leading to him altering his will to protect Judith against her

\footnotetext{
${ }^{48}$ As it turned out, Susanna had no sons, Elizabeth had no sons or daughters, and although Judith had three sons (including Shakespeare Quiney, conceived in his grandfather's lifetime, born in November 1616, and dead in May 1617), she and they all died before Elizabeth, who lived until 1670.
} 
husband. There is no evidence of this in our re-reading, which dates page 1 to 25 January 1616, and not 25 March 1616.

However, the will as written in January modified a pre-existing settlement, with the unusual addition of making some provision for her husband-to-be. Tying up money for a daughter's benefit was an utterly standard provision in a wealthy gentleman's will. What is not standard about William Shakespeare's will is that he also provided the new husband with money to settle upon his wife. This, rather than being a sign of animosity between Shakespeare and Thomas Quiney, demonstrated his support of the young man.

A lot has been made of the crossing out of the words 'sonne in l' on the first page, as an indication that Shakespeare had severe doubts about Thomas Quiney. It is far more likely that it was a slip of the tongue, taken down in dictation: Thomas was being thought of as a son in law, but was not yet actually one. Better practice was just to name Judith. However, this crossing-out does provide an interesting glimpse into the conversation and intention behind the text: Shakespeare and Collins had been discussing how best to provide for Thomas and Judith as a couple, not just Judith. The new page 1 is longer than the one (from 1613) that it replaced: towards the last third of the page, the spacing becomes increasingly cramped. The provision for Judith had become more complicated with an imminent marriage than that made in 1613 for a future marriage.

In fact, although it is quite difficult to disentangle, it is a cleverly drafted will, and, as indicated below, one which is generous to Judith and her husband-to-be, and to Judith in any future situation which may develop. ${ }^{49}$ The will was signed off on Thursday, 25 January, and Judith and Thomas married on Saturday, 10 February 1616.

\section{A detailed look at the provision for Judith}

Judith was given $\mathcal{f} 100$ as her marriage portion (granted we think some years earlier in the family settlement), to be raised from the estate within a year after her father's death. This was a sum usually described as payable on marriage, but payment of which was often deferred until the father's death. If Shakespeare had lived another 10 years, Judith would have had to wait for it. She was also offered a further $£, 50$ after her father's death if she surrendered any claim as co-heir with her elder sister to the cottage in Chapel Lane, Stratford, held by copyhold tenure of the manor of Rowington, which Shakespeare had acquired in $1602 .^{50}$

However, if Judith (or any of her children) were still alive in three years after the date of the will (so, 1619), she was promised a further $\mathcal{E}_{150}$ to be paid over direct to her husband, if he matched her portion $(£, 100)$ by settling the same amount in lands on her and her children [that is, made a family settlement with a jointure in lands on Judith]. ${ }^{51}$ The same terms would apply if Thomas died before then and she married again. If Judith's husband had not settled lands of equivalent value on her, or if she were a widow, the $\mathcal{N} 150$ was to be used by the executors of the will to generate an annual income for Judith or her children, by placing it upon trust for Judith for life, with remainder to her issue, if any. This would have given Judith a 'separate estate' even if

\footnotetext{
${ }^{49}$ It is particularly difficult to grasp because of the interpolation of provisions in case of Judith's death without children, leaving some of the money to William's sister Joan Hart and granddaughter Elizabeth Hall instead.

${ }_{50}$ A copyholder could surrender the copyhold to the use of his will, and devise the land by testament. See C.M. Gray, Copyhold, Equity and the Common Law (Cambridge, Mass., 1963), 14-15.

51 There is an interesting distinction between $£ 100$ a year after William's death, and $£ 150$ three years after the date of his will, to be administered by his executors. Does it imply that he expected to be dead within three years?
} 
married, where under certain circumstances she would have trustees allowing her to have full control over the annual income coming from the $\mathcal{N}_{150}$ capital. In addition, this money would not be available to any creditors her husband may have had.

So this part of the will modified the pre-existing settlement, with Shakespeare being very careful of Judith's present and future, both with Thomas Quiney and with any future husband. In offering to give a son in law $\mathcal{E}_{1} 150$ cash to cover the purchase of $\mathcal{E}_{100}$ in property, he was almost acting in the role of the bridegroom's father. Shakespeare was effectively making sure that Judith had an annuity even if she did not get a jointure, and was putting his executors (Susanna and John Hall) in the role of trustees. The long-term nature of this trust may explain why his wife Anne was not named as an executor: Susanna and John Hall were more likely to live as long as Judith. Moreover, it shows Shakespeare's generosity to Judith and Thomas; the whole settlement was designed to protect and provide for Judith, not to disinherit her. Provision for daughters in this period (and for the next three centuries) usually meant protection, and it is in this sense that we must read the intentions behind the will.

Does all this imply something about Shakespeare's opinion of Thomas Quiney? It has often been read as indicating that he distrusted Thomas, and was trying to stop him from wasting Judith's inheritance. This is a common but false reading of this type of device, which had to be strongly worded to achieve its effect in law. ${ }^{52}$ It probably implies more about his opinion of Judith: that she deserved his continued protective care even after his death.

However, we should not discount Thomas's family background. His father Richard Quiney, then bailiff of Stratford and head of a senior Stratford family, died after being attacked in 1602 by men of Sir Edward Greville, in the course of long-running disputes between the town and Greville in which Shakespeare was peripherally involved..$^{53}$ Thomas was 13 on his father's death: one of several children left for their mother to bring up. With this family history, intimately known to the Shakespeare family, the provision of long-term security for wife and children against the potential tragedies of life would have been of direct relevance and importance. Shakespeare behaved towards Thomas with generosity, acting as both father and father in law in setting the couple towards a successful marriage..$^{54}$

\section{The bequest of his plate to his grand-daughter}

Plate means silver or silver gilt in the form of vessels - plates, bowls, jugs etc. It was a handy form of storing silver, combining display of wealth with the possibility of easy conversion into coin at the mint. Since we do not know what plate Shakespeare had, we cannot judge the value of this bequest, except that it formed a portable wealth, bought at a time when there was increasing expectation that a gentleman would have a good supply of gold and silver vessels on display and for use. Any plate may have been bought in London, perhaps at Goldsmiths Row in Cheapside, and brought home. We do know that he valued his plate aesthetically: in January 1616 when this bequest was

\footnotetext{
52 'The language used to establish a separate estate may suggest to later readers some animosity between father and son-in-law . . . but such was not necessarily the case, since the vigorous phrasing was legally required to achieve the desired effect of a daughter's security', Erickson, Women and Property, 124.

53 Richard Quiney asked for Shakespeare's help, in the only extant letter to him, addressing him as 'loveinge contreyman', Shakespeare Birthplace Trust, ER 27/4.

54 Thomas Quiney is often dismissed as unsuccessful, but a year after marriage he was admitted as a burgess of Stratford, and ran a long-term business as vintner and tobacconist, dealing in imported luxuries: this is not failure.
} 
altered to go to his grand-daughter Elizabeth, he specified that Judith should still get 'my brod silver gilt bole', mentioning it twice.

Leaving the plate to Elizabeth meant that her parents, the executors, could not sell it to pay the bequests, although they could continue to use it until she came to set up her own household on marriage. Shakespeare was effectively providing the only grandchild he knew with the means of making a good marriage, by giving her a dowry not dependent upon waiting for her own parents' death. Perhaps he already recognised that she was likely to be his heiress.

\section{So where does this leave Anne Shakespeare?}

Shakespeare's treatment of his wife in his will has given rise to much speculation. Anne was not named as an executor nor as a major beneficiary. Many have assumed from this a want of good relations between husband and wife (to put these speculations in the most favourable light), or a want of capacity in Anne herself. However, the way the will was framed required executors potentially to act as trustees for the length of Judith's life or for those of any children she may have left, not merely paying an annuity but also generating the annuity from capital. This was potentially too longterm a burden to lay on someone from the previous generation. Had Anne been named executor, she would have all the labour and none of the reward. Instead Susanna and John Hall, although inheriting the real property, were burdened with raising significant sums of cash from that part of the property not previously assigned to Anne.

For Anne herself was not left unprovided. As a widow, she was possessed either of dower covering a third of the land of which her husband had been seised during her coverture or of a jointure in specific properties under the earlier family settlement. If these were not mentioned in the will, that was because there was no need to mention them. ${ }^{55}$ Dower operated at common law, whilst a jointure was settled by an inter vivos deed: hence, both dower and jointure necessarily took effect outside the will. Anne's existing rights as a wife and widow would have been unalterable by will, and would have burdened the inheritance for her lifetime. In addition, she would have been entitled by law to her paraphernalia for life (i.e. her clothes, jewels and ornaments, suitable to her station): as with dower and jointure, paraphernalia did not need to be mentioned in a will.

It has been claimed that the Blackfriars Gatehouse was bought and placed in trust in 1613, to the use of Shakespeare, to deny Anne any claim to it in dower, as a mark of disfavour. Whilst one aim of the conveyance in trust may indeed have been to avoid Anne's dower, we cannot necessarily infer from this fact that Shakespeare harboured ill feeling towards his wife. On the same evidence, we might equally surmise that Shakespeare purchased the property in trust in order to preserve an unburdened title to the land which he could then pass to his heir, or indeed, any later purchaser. Putting the Gatehouse in trust made it easier to sell because any future purchasers would be protected against a claim in dower by the widow of a previous owner. The purchase in trust was, therefore, a nod to contemporary conveyancing practices and the need to preserve an unburdened title to land. This argument is strengthened by the fact that, in February 1618, the Gatehouse was transferred from the trustees of William Shakespeare to new trustees for his heirs (Susanna and John). ${ }^{56}$ That Susanna and John

\footnotetext{
55 'Annual maintenance payments, in the style of a jointure, were rarely mentioned in wills in any place so far studied in England', Erickson, Women and Property, 164.

${ }_{56}$ Folger Shakespeare Library, MS Z.c.22 (44), viewable online at http://www.shakespearedocumented.org.
} 
thought it worthwhile to keep the property in trust indicates that the advantages of trust-holding outlived any claim in dower that Anne may have had to the property. Moreover, had John and Susanna taken the property out of the trust and held the legal title to the land directly, Susanna would herself have had a claim in dower against the land. Retaining the property in trust after William's death was, therefore, a prudential step in avoiding any right to dower that might attach to the land, thus preserving the resale value of the Gatehouse.

There is also the lease for 31 years of part of the great and small tithes of the parish of Old Stratford, bought for $\mathcal{E}_{404}$ in 1605 and not clearly mentioned in the will. ${ }^{57}$ This lease of tithes was supposed to have brought in an annual income of between $£ 40$ and f60. It is possible that part of this had been granted to Anne by her husband in the inferred family settlement. The lease was not sold back to the corporation of Stratford by Susanna and John Hall until 1 March 1625, so it is possible that some of the tithe income was due to Anne between his death in 1616, and hers in August 1623. Holding the right to the great tithes allowed Shakespeare to be buried in the chancel of the parish church as a lay rector; perhaps it is significant that Anne, Susanna and John were also buried in the chancel.

\section{Alterations in March 1616}

Looking at the will as a whole, one can see a number of changes in a slightly darker ink, which we think were made in late March or in April 1616. ${ }^{58}$ They begin with the date clause on page 1. Here 'Januarii' has been replaced by 'Martii'. On page 1 is the clarification of Judith's initial $f, 100$ as her marriage portion; on page 2 the bequest of mourning rings to his old Stratford friends Hamnet Sadler and William Reynolds, and to his theatre 'fellowes' John Heminges, Richard Burbage and Henry Condell, and the clarification that Susanna must put her inheritance towards fulfilling the bequests; and on page 3, the well-known 'item I gyve unto my wife my second best bed with the furniture'.

The two provisions concerning Judith and Susanna were to ensure against potential dispute and to stress that Susanna must look after her wider family. The others are bequests of affection - not great in substance, but expressive of a wish to mention the people of importance in his life, and to provide them with a physical memento. They are the only overt signs of emotional engagement among the planned disposition of property, added as death came closer: mourning rings to old and dear friends and colleagues, and to his wife a specific bequest that only the two of them could fully understand.

Was the second best bed an insult? The first best bed in a gentleman's house was often kept for high-status visitors, and was by custom treated as an heirloom to descend to the heir. ${ }^{59}$ Modern readings tend to stress second-best as derogatory: but it should be read as second best - it was a statement of quality in a house full of beds. The second best bed in New Place, a grand house with ten bedrooms, was likely to have been an expensive piece of furniture, and perhaps even the marital bed of their nearly twenty

\footnotetext{
57 The lease of tithes could perhaps just be included in the bequest to Susanna of 'all . . hereditaments whatsoever ... to be had [or] received . . . within the townes . . . of Stratford upon Avon', but it seems unlikely, given that they represent the large income of $£ 40-£ 60$ a year.

58 The darker ink of these interlineations was noted by Rogers, The Second Best Bed, 18

59 Jacob, Law Dictionary, ed. Tomlins, under HEIR LOOME: 'comprehends divers implements of household, such as the first best bed and other things, which by the custom of some countries have belonged to a house for certain descents ... [and] accrue to the heir with the house itself'.
} 
years there. Gentry beds were becoming objects of luxury, as the consumption of fine goods spread. ${ }^{60}$ Shakespeare specifically left Anne this bed as a gift, to dispose of as she willed, not just for the term of her life. It would be interesting to know if she left it to Judith.

\section{One last problem}

There is one last problem with the will: the change of the date from 25 January 1616 (a Thursday), to 25 March 1616, by the simple substitution of the month. Monday, $25^{\text {th }}$ March was an important day in 1616. It was both the day after Palm Sunday, and also the feast of the Annunciation, Lady Day - and as such the first day of the new year 1616 as reckoned at the time. Shakespeare and Francis Collins, on drafting the will in January, should have given the date then as January 1615. In fact, they expressed it three incompatible ways - by the year 1616, and by the two regnal years of England (14 James I - which implies their 1617: they should have put 13 James I) and Scotland (49 James VI - which is accurate). This caused great confusion all round when we made the films: much puzzled counting on fingers, as the Handbook of Dates does not include the Scottish regnal years. The problem has been noted before, but has been explained by the view that page 1 was completely re-written on 25 March (when the year was right) but incorporating an errant January date from the previous draft. ${ }^{61}$ Brock has called the reiteration of 25 th ' a coincidence as potentially as suspect as the date of his birth and death both falling on 23 April'. ${ }^{62}$

It is indeed odd and somewhat unlikely that these corrections should have been made on the exact same numeric day, the 25th. And yet, by choosing an amendment which simply corrects the month and leaves the rest of the dating clause intact, all the other dates fall into place. Perhaps Collins' clerk just put the wrong calendar year in January. What was wrong and incompatible on 25 January becomes right and compatible on 25 March.

This raises a further question: were these corrections actually written on 25 March, or was that the most convenient date to which to ascribe a correction, given that the day of Shakespeare's death was 23 April? We know that his brother-in-law, William Hart who lived in the Henley Street house, also died in Stratford and was buried on 17 April. The will does not have any annotation naming Joan Hart as a widow, so perhaps we can narrow the date of the very last recension of Shakespeare's will to between 25 March and 15 April 1616.

These late interlineations are not large changes, just the kind of thoughts that a dying man might dwell on, about people of real and enduring importance in his life, people who would appreciate that they were in his mind as he faced the approach of death. If the family were in agreement, why would anyone raise the additions as an issue?

And no one did, for the will was proved by John Hall in London on 22 June 1616. Official copies were made, smoothing out all the changes into an authoritative text, and all the drafting and redrafting and additions made by Francis Collins and William Shakespeare on the three sheets of paper were left behind in the archives, to cause puzzlement for future readers.

\footnotetext{
${ }^{60}$ Natasha Korda, Shakespeare's Domestic Economies: Gender and Property in Early Modern England, (Philadelphia, 2015), 18-19.

${ }_{61}$ Chambers, William Shakespeare, II, 175.

62 Susan Brock, 'Last things: Shakespeare's neighbours and beneficiaries', in The Shakespeare Circle: An Alternative Biography, ed. Paul Edmondson and Stanley Wells (Cambridge, 2015), 213.
} 


\section{Reflections on interdisciplinary research}

This article has attempted to combine several strands of research in order to illuminate certain aspects of Shakespeare's final years. In embarking upon research of this nature, however, we encountered a number of methodological pitfalls. We found, for example, that whilst much of the scholarship on the will has proceeded from those who had studied the life and works of Shakespeare in great detail, little of that work had considered the broader legal historical context in which it was drafted. Similarly, we found that significant research has been conducted upon the history of conveyancing in this period but that such scholarship has tended toward the exploration of legal doctrine and has rarely been applied to explain the deeper aspects of historical biography.

To that end, in presenting this work, we have sought to detail the process by which this research emerged and proceeded. By reflecting on the processes by which new understandings and interpretations of the past are produced, the paramount importance of the environment in which such research takes place can be seen. Combining sociohistorical and legal-historical critiques with scientific and technical analyses in the formality of meeting rooms and the admittedly more relaxed atmosphere of TNA's café was crucial to the free flow of ideas. This convivial atmosphere was particularly crucial as we grappled with some of the more knotty methodological issues so typical of interdisciplinary research. This article is merely one attempt to avoid some of these pitfalls and bridge some of the gaps between the disciplines of law, history and biography and it is hoped that similar, collaborative work will continue to aid interpretations of the will in the future. 


\section{Appendix: Shakespeare's original will (TNA: PROB 1/4)}

In this transcription, the dark-ink interlineations now considered to be from March 1616 are in bold.

[Folio 1]

Vicesimo Quinto die fanturit Martii Anno Regni Domini nostri Jacobi nunc Regis Angliae decimo quarto \& Scotie xlixo Annoque Domini 1616

Wm Shackspeare [added by the court]

In the name of god Amen I William Shackspeare of Stratford upon Avon in the countie of Warr' gent in perfect health and memorie god by praysed doe make and Ordayne this my last will and testament in manner and forme followeing That ys to saye first I Comend my Soule into the hands of god my Creator hoping and assuredlie beleeving through thonelie merittes of Jesus Christe my Saviour to be made partaker of lyfe everlastinge And my bodye to the Earthe whereof yt ys made. Item I Gyve and bequeath unto my sonne in $L$ Daughter Judyth One Hundred and fyftie pounds of lawfull English money to be paied unto her in manner and forme follewing That ys to saye One Hundred Poundes in discharge of her marriage porcion within one yeare after my deceas with consideracion

after the Rate of twoe shillinges in the pound for soe long tyme as the same shalbe unpaid unto her after my deceas \& the fyftie pounds Residewe therof upon her surrendering of or gyving of such sufficient securitie as the overseers of this my will shall like of to Surrender or graunte All her estate and Right that shall discend or come unto her after my deceas or that she nowe hath of in or to one Copiehold tenemente with theappertenances lyeing \& being in Stratford upon Avon aforesaied in the saide countie of warr' being parcell or holden of the mannor of Rowington unto my daughter Susanna Hall and her heires for ever. Item I gyve and bequeath unto my saied Daughter Judith One Hundred and ffyftie Poundes more if shee or Anie issue of her bodie be Lyvinge att thend of three yeares next ensueing the daie of the date of this my will during which tyme my executors to paie her consideracion from my deceas according to the Rate aforesaied. And if she dye within the saied terme without issue of her bodye then my will ys and I doe gyve and bequeath One Hundred Poundes therof to my Neece Elizabeth Hall and the ffiftie Poundes to be sett fourth by my executors during the lief of my Sister Johane Harte and the use and proffitt therof cominge shalbe payed to my saied Sister Jone and after her deceas the saied L li [ $\left.\mathcal{L}^{50}\right]$ shall Remaine Amongst the children of my saied Sister Equallie to be devided Amongst them But if my saied daughter Judith be lyving att thend of the saied three yeares or anie issue of her bodye then my will ys and soe I devise and bequeath the saied Hundred and ffyftie poundes to be sett out by my executors and overseers for the best benefit of her and her issue and the stock not to be paied unto her soe long as she shalbe marryed and Covert Baron by ne mill ys that she shall have the consideracion yearelie paied unto her during her lief and after her deceas the saied stock and consideracion to bee paid to her children if she have Anie and if not to her executors or Assignes she lyving the saied terme after my deceas provided that if 
such husbond as she shall att thend of the saied three yeares be marryed unto or attain after doe sufficiently Assure unto her and thissue of her bodie landes awnswereable to the portion by this my will gyven unto her and to be adjudged soe by my executors and overseers then my will ys that the saied CL li [£150] shalbe paied to such husbond as shall make such assurance to his owne use Item I gyve and bequeath unto my saied sister Jone XX li $[£ 20]$ and all my wearing Apparell to be paied and delivered within one yeare

after my deceas. And I doe will and devise unto her the house with thappurtenances in Stratford wherein she dwelleth for her naturall lief under the yearelie Rent of xiid Item I gyve and bequeath

William [Shakespeare crumbled away - and in a different place from $\mathrm{p} 2$ ]

[Folio 2]

unto her three sonnes William Hart [blank] Hart and Michaell Harte ffyve pounds A peece to be payed within one yeare after my deceas to be sett out for her withrin one yeare after my deceas by my executors with thadvise and direceons of my overseers for her best proffitt untill her marriage and then the same with the increase there of to be paied unto frer. Item I gyve and bequath unto her the said Elizabeth Hall All my Plate (except my brod silver and gilt bole) that I now

have att the date of this my will Item I gyve and bequeath unto the Poore of Stratford aforesaied tenn poundes to Mr Thomas Combe my Sword to Thomas Russell Esquier ffyve poundes and to Frauncis Collins of the Borough of Warr' in the countie of Warr' gent thirteene poundes Sixe shillinges and Eight pence to be paied within one yeare after my deceas Item I gyve and bequeath to Hamlett Sadler mr Richard Fyler theter xxvjs viijd [26s 8d] to buy him A Ringe; to william Raynoldes gent xxvjs viijd to buy him a Ringe; to my godson William

Walker xxvjs viijd in gyld to Anthony Nashe gent xxvjs viijd to mr

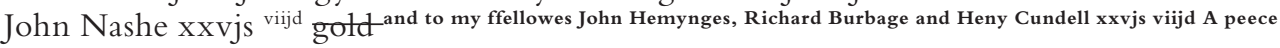
to buy them Ringes. Item I Gyve Will Bequeth and Devise unto

my Daughter Susanna Hall for better enabling of her to performe this my will and towardes the performans thereof All that Capitall Messuage or tenemente with thappertenaces in Stratford aforesaid called the newe place wherein I now Dwell and two messuags or tenementes with thappurtenances scituat lyeing and being in Henley Streete within the borough of Stratford aforesaied And all my barnes, stables, Orchardes, gardens, landes, tenementes and hereditaments whatsoever scituat lyeing and being or to be had receyved, perceyved or taken within the townes and Hamletts, villages, ffieldes and groundes of Stratford upon Avon, Oldstratford, Bushopton and Welcombe or in anie of them in the saied countie of warr And alsoe All that Messuage or tenemente with thappurtenances wherein one John Robinson dwelleth, scituat lyeing and being in the blackfriers in London nere the Wardrobe and all other my landes tenementes and hereditamentes whatsoever. To Have and to hold All and singular the saied premisses with their Appurtenances unto the saied Susanna Hall for and during the terme of her naturall lief and after her deceas to the first sonne of her bodie lawfullie yssueing and to the heires Males of the bodie of the saied first sonne lawfullie 
yssueinge and for defalt of such issue to the second sonne of her bodie lawfullie ysueinge and $f$ to the heires males of the bodie of her saied Second Sonne lawfullie yssueinge and for defalt of such heires to the third sonne of the bodie of the saied Susanna Lawfullie yssueinge and of the heires males of the bodie of the saied third sonne lawfullie yssye ing And for defalt of such issue the same soe to be and Reamine to the ffourth somne, ffythe, sixte and seaventh sonnes of her bodie lawfullie issueing one after Another and to the heires

William Shakspeare

\title{
[Folio 3]
}

Males of the bodies of the saied ffourth, ffythe, Sixte and Seaventh sonnes lawfullie yssueing in such mamer as yt ys before Lymitted to be and remaine to the first, second and third Sonns of her bodie and to their heires males And for defalt of such issue the saied premisses to be and Remaine to my sayed neece [Elizabeth] Hall and the heires Males of her bodie Lawfully yssueing [and] for defau[lt of] such issue to my daughter Judith and the heires males of her bodie lawfullie issueinge And for defalt of such issue to the right heires of me the saied William Shackspeare for ever. Item I gyve unto my wief my second best bed with the furniture Item I gyve and bequeath to my saied daughter

Judith my broad silver gilt bole All the rest of my goodes Chattels

Leases plate jewels and Household stuffe whatsoever after my dettes and Legasies paied and my funerall expences discharged, I gyve devise and bequeath to my Sonne in Lawe John Hall gent and my daughter Susanna his wief whom I ordaine and make executors of this my Last will and testament And I doe intreat and Appoint the saied Thomas Russell Esquier and Frauncis Collins gent to be overseers hereof And doe Revoke All former wills and publishe this to be my last will and testament In witnes whereof I have hereunto put my feate hand the Daie and Yeare first above written.

By me William Shakspear

Witness to the publishing hereof: Fra Collyns

\section{Juilyus Shawe \\ John Robinson \\ Hamnet Sadler \\ Robert Whattcott}

\author{
Probatum coram Magistro Williamo Byrde \\ legum doctore Commissario etc xxiido die \\ mensis Junii Anno domini 1616 Juramento \\ Johannis Hall unius executorum etc. Cui etc \\ de bene etc Jurati Reservata potestate \\ etc Sussane Hall alteri executorum etc cum \\ venerit etc petitur. \\ Inventarium exhibitum.
}

